\title{
Prior Restraints in Public High Schools
}

That the First Amendment freedom of speech applies to students in the public high school context was settled by Tinker $v$. Des Moines Independent Community School District. ${ }^{1}$ Students invoking the Tinker right have sometimes raised the question whether schools can require them to submit publications they wish to distribute on school premises for advance approval. Stated in other terms, the question has been whether schools are entitled to impose prior restraints on printed material.

After Tinker, the regulations governing distribution of materials varied among schools. Some regulations specifically prohibited prior restraints. ${ }^{2}$ Others were ambiguous. ${ }^{3}$ Still others clearly required the prior approval of the content of material to be distributed. From among this latter class of regulations there arose several lawsuits asserting that such regulations are impermissible. Four such lawsuits reached

1. 393 U.S. 503 (1969). Tinker does not consider the First Amendment rights of students in private high schools. This Note is likewise addressed only to public sehools. It should be observed, however, that many commentators argue that every school is a public in. stitution. Wright, The Constitution on the Campus, 22 Vaxp. L. REv. 1027, 1035 (1969): see, e.g., Cohen, The Private-Public Legal Aspects of Instilutions of Higher Education, 45 DeNVER L.J. 643 (1968).

Nor does this Note deal with prior restraints on the right of association or assembly. The Supreme Court recently addressed these questions in the college context. See Healy v. James, 408 U.S. 169 (1972). Finally, this Note is confined to an examination of the question of prior restraints on student expression. Expression by outsiders on school premises is subject to additional considerations.

2. In 1970 the Philadelphia Board of Education approved a High School Bill of Rights. An accompanying memorandum, in discussing the distribution of printed material and petitions, says, "There shall be no prior censorship or requirement of approval of the contents or wording of such material . . P. Lines, Codes Governing Rights and Conduct of High School Students 74, Apr. 15, 1971 (Center for Law and Education, Harvard University).

In San Francisco, almost identical wording was adopted by the Board of Education in March 1971:

Students shall be free to distribute handbills, leaflets and other printed material

and to collect signatures on petitions concerning cither school or out-of-school

issues, whether such materials are produced within or outside the school. There

shall be no prior censorship or requirement of approval of the contents or wording

of such material ....

Id. at 99 .

3. For example, in 1970 the State Board of Education of Washington promulgated guidelines to assist local school districts in preparing regulations dealing with students" rights. The guidelines, however, suggest only that regulations must be "reasonable," and that schools should "develop creative ways of providing time and space for student expression." Id. at 148-49. In 1971 the Massachusetts Department of Education. Youth Advisory Council, issued Guidelines for Student Rights and Responsibilities. These included an entire section on students First Amendment rights, without a single reference to prior restraints. In one sentence almost calculated to foster uncertainty, the rcgulations said, "[N] on-school sponsored student publications should be subjected to locally determined procedures for distribution on school premises." Id. at 159.

4. The cases which have arisen are themselies proof that there are major school districts which have imposed prior restraints on student expression. See pp. 1330.33 infra. 
four different federal courts of appeals. In three, the courts ruled that the regulation was invalid because it was procedurally defective, but that a properly drafted regulation requiring advance submission would be permissible. The fourth court also held the regulation invalid, but on the ground that prior restraints could not be constitutionally imposed in high schools.

This Note argues that Tinker does not authorize the imposition of prior restraints in high schools. Properly understood, the case is fully consistent with the general principle that speech may be regulated because of its potential for producing disorder; but such regulation cannot take the form of prior restraints.

Student rights of speech derive from general legal doctrines governing freedom of expression which, in turn, are rooted in the First Amendment. The Amendment, despite its absolute language forbiclding laws which abridge freedom of speech, 5 is properly read "to permit reasonable regulation of speech-connected activities in carefully restricted circumstances."'

Perhaps the most important justification for regulation of "speechconnected activities" is the prevention of disorder. The possible sources of disorder are conceptually twofold: the manner of the exercise of speech, and its content. In preventing disorder arising from the first of these two, the state may prescribe reasonable "time, place and manner" regulations which provide a procedural framework for the exercise of First Amendment rights. ${ }^{7}$ Their purpose is to allocate limited societal resources fairly among competing demands. They may not concern the content of speech, nor may they entirely foreclose the oppor-

5. U.S. CoNst. amend. 1. The First Amendment applies to the states by virtue of the Fourteenth Amendment. Gitlow v. New York, 268 U.S. 652, 666 (1925).

6. Tinker v. Des Moines Ind. Comm. School Dist., 393 U.S. 503, 513 (1969).

7. Regulations that govern the time and place of expression make no reference at all to its content. Regulations of time state the permissible periods for expression or the permissible duration of expression. Typically, such a regulation would prohibit distri. bution of printed matter during class time. Regulations of place are similarly oriented. They might forbid circulating material in the nurse's office, for example. Sec generally $T$. EMERSON, THE SYSTEM OF FREEDOM OF Expression 298-310 (1970). Regulations governing the manner of expression are more difficult to define:

"Manner" should be understood to denote only those physical and procedural in. cidents of public expression that are neither "time" nor "place"-for example, the size and number of posters that can be displayed in various locations, the volume of sound amplification, chairmanship of public meetings, identification of persons soliciting funds, methods of distributing literature, and the myriad other matters that must be regulated in order effectively to regulate the speech situation.

O'Neil, Reflections on the Academic Senate Resolution, 54 CALIF. L. REv. 88, 104 (1966). 
tunity for expression. They must be carefully drawn so as to limit the discretion of the officials who administer them, ${ }^{8}$ and may never be used to prevent the expression of unpopular opinions.

The state is also permitted to regulate speech to prevent disorder caused by its content. Three important issues are involved in instances of regulation for this purpose. One is the legal standard of the degree of threatened disorder which justifies interference with speech. A second is the reasonableness of the state's determination that such a threat exists in a particular circumstance. The third issue, which is really a derivative of the first two, is the appropriate timing of state intervention.

The most recent expression of the Supreme Court regarding the legal standard is that the state may intervene where "advocacy is directed to inciting or producing imminent lawless action and is likely to incite or produce such action." In evaluating the reasonableness of an interference based on incitement, the content of the speech is certainly relevant, but can hardly be regarded as determinative. The second half of the standard would seem to require an analysis of the context of the speech, particularly the reaction of its audience. Regard for the facts of actual audience response anchors a court's determination in the realities of a case, and enables it to serve as an effective check on the actions of officials who may be overly cautious or who may wish to prevent the expression of certain viewpoints.

This resolution of the first two issues suggests an answer to the third, the timing of intervention: There should be a presumption against the validity of intervention occurring before speech has been initiated. Such "prior restraint" brings the question of the reasonableness of state action to the courts without a framerwork of facts as to the evil to be forestalled-facts as to the actual results of speech, not merely its possi-

8. In Shuttlesworth v. Birmingham, 394 U.S. 147 (1969), the Court struck down a statute which gave the City Commission virtually absolute power to prohibit any demonstration or parade on the city's streets or public ways because of the discretion left with city officials to issue or deny permits for demonstrations. By comparison, in Cox v. Louisiana, 379 U.S. 559 (1965), the Court upheld a statute which left to the discretion of administrative officials the decision as to when a demonstration was "near" a courthouse. The Court reasoned that the discretion involved was "not the type of unbridled discretion which would allow an official to pick and choose among expres: sions of view the ones he will permit to use the streets and other public facilities . . .." Id. at 569.

9. Brandenburg v. Ohio, 395 U.S. 444,447 (1969).

Brandenburg echoes the classic "clear and present danger" test in requiring an examination of the circumstances as well as the content of expression: "The question in every case is whether the words used are used in such circumstances and are of such a nature as to create a clear and present danger that they will bring about the sub. stantive evils that Congress has a right to prevent." Schenck v. United States, 249 U.S. 47,52 (1919). 
ble consequences. The absence of such facts from the court's considerntion inevitably reduces the probability that judicial supervision will be adequate. ${ }^{10}$

Indeed, prior restraints have long been disfavored in Anglo-American law. ${ }^{11}$ Most recently, the unconstitutionality of prior restraints in most situations was reaffirmed by the "Pentagon Papers" censorship case. There, the Supreme Court reiterated that the government "carries a heavy burden of showing justification for the imposition of such a restraint." 12 The combined effect of the diverse opinions in that case was to emphasize the constitutional judgment that, while speech may be regulated, such regulation must ordinarily be based upon an analysis of the speech in question within the factual context of its publication. ${ }^{13}$

II

Any doubt about the applicability of the First Amendment to student expression was removed in 1969, when the Supreme Court decided Tinker v. Des Moines Independent Community School District. ${ }^{14}$ The Court's basic premise was that,

10. Particular facts are so important that courts refuse to permit regulation on the basis of experience in previous similar events. See Kunz v. New York, 340 U.S. 290, 294.95 (1951):

The court below has mistakenly derived support for its conclusion from the cvidence -. . that appellant's religious meetings had, in the past, caused some dis. order. There are appropriate public remedies to protect the peace and order of the community if appellant's specches should result in disorder or violence . . . . Wo do not express any opinion on the propriety of punitive remedies which the New

York authorities may utilize. We are here concerned with suppression-not punish. ment.

In National Socialist White People's Party v. Ringers, Civil No. 72-1737 (4th Cir., filcd Feb. 5, 1973), a school board had refused to rent a school auditorium to the Party despite the general availability of the auditorium for public and private use. The court held the denial improper, observing that, "[e]ven if the record showed some history of violence attendant upon the Party's meetings, or some threat of violence by hostilc spectators, it would not constitute a proper basis for restraining the Party's otherwisc legal first amendment activity." Id. at 8 n.4.

11. The ban against prior restraints has a long history reaching back to the common law of England in the eighteenth century. When the First Amendment was adopted in 1791 , it was clearly intended to include the common law position against prior restraints. See Emerson, The Doctrine of Prior Restraints, 20 LAw \& ConTEMP. Pko8. 648, 651.52 (1955).

12. New York Times v. United States, 403 U.S. 713, 714 (1971), quoling Organization for a Better Austin v. Keefe, 402 U.S. 415, 419 (1971). The Times Court also quoted from Bantam Books, Inc. v. Sullivan, 372 U.S. 58, 70 (1968): "Any system of prior restraints of expression comes to this Court bearing a heavy presumption against its con. stitutional validity." 403 U.S. at 714 .

13. There is, of course, the danger that regulations of timc, place and manner will be applied, not only as neutral traffic regulations, but also as a means of weeding out in advance exercises of speech deemed undesirable. Because of this danger, regulations which purport to govern time, place and manner, but which may allow disguised cont. trols on content-because they are vague or grant excessive administrative discretion-arc likely to be characterized judicially as prior restraints. See note 8 supra. See generally Monaghan, First Amendment "Due Process," 83 HARv. L. REv. 518, 599-43 (1970).

14. 393 U.S. 503 (1969). In Tinker junior and senior high school students were sus. pended for wearing black armbands to school to dramatize their opposition to the war 
[i]n our system, state-operated schools may not be enclaves of totalitarianism. School officials do not possess absolute authority over their students. Students in school as well as out of school are "persons" under our Constitution.... In the absence of a specific showing of constitutionally valid reasons to regulate their speech, students are entitled to freedom of expression of their views. ${ }^{15}$

Proceeding to define those "constitutionally valid reasons," the Court focused on the "special characteristics of the school environment,"10 and concluded that regulation of students' speech is improper unless there is a showing of "facts which might reasonably have led school authorities to forecast substantial disruption of or material interference with school activities, [or if] disturbances or disorders on the school premises in fact occurred."17 Since neither condition was met in Tinker, the regulation there was declared invalid.

That part of the Tinker standard which allows regulation to be based on the "forecast" of disruption has inevitably attracted litigation. Courts have been asked to determine whether it is proper, as a means of making that forecast, to require students to submit for prior approval any printed matter they wish to distribute on school premises.

At its core, the question is whether Tinker sanctions prior restraints in the school setting when they are impermissible in society generally, i.e., whether the school's special need for order justifies a forecast made only on the basis of content, without more "facts" as to actual effect. While plaintiffs challenging such regulations have uniformly prevailed, most courts have declined to hold prior restraints per se inappropriate in high schools. At the moment, there is a clear majority and minority rule in the federal courts of appeal on this question. The majority rule, endorsed by the Second, Fourth, and Fifth Circuits, is that prior restraints applied through systems of advance submission of materials are permissible in high schools if they include adequate safeguards. These safeguards include criteria for determining forbidden material, prompt decisions concerning permission to distribute and, in some circuits,

in Vietnam. The armbands were worn just before the Christmas holiday season in defiance of a policy adopted by Des Moines school principals on December 14 that pro. hibited the wearing of armbands in schools. The Supreme Court held that the activities of high school students were protected by the First Amendment "applied in light of the special characteristics of the school environment." Id. at 506.

15. Id. at 511 .

16. Id. at 506 .

17. Id. at 514. The test adopted was taken from Burnside v. Byars, 363 F.2d 744, 749 (5th Cir. 1966):

Certainly where there is no finding and no showing that engaging in the forbidden conduct would "materially and substantially interfere with the requirements of appropriate discipline in the operation of the school," the prohibition (of expression) cannot be sustained. Burnside v. Byars, supra, at 749 . 393 U.S. at 509. 
speedy appeal from adverse decisions. The minority rule, adopted so far only by the Seventh Circuit, is that prior restraints are wholly inappropriate in high schools.

The leading case for the majority rule is Eisner v. Stamford Bourd of Education. ${ }^{18}$ Plaintiffs, students at a public high school in Connecticut, were publishers of a mimeographed newspaper entitled the Stamford Free Press. They had distributed three issues off school grounds with. out incident. In response to attempts to circulate the fourth issue on school grounds, the Board of Education promulgated a regulation forbidding the distribution of written matter on school premises without the prior approval of the school administration. The students thereupon sued for declaratory and injunctive relief. ${ }^{10}$ The Second Circuit, declining to adopt the alternative theory of the district court that prior restraints are impermissible in high schools, ${ }^{20}$ held that the specific regulation in question was void for procedural inadequacies." ${ }^{21}$

In Quarterman v. Byrd, ${ }^{22}$ the Fourth Circuit followed Eisner's lead in sanctioning prior restraints. A tenth-grade student had twice been suspended for distribution of an underground newspaper in violation of a school rule which required the permission of the high school principal to distribute written material in the school. ${ }^{23}$ The court struck

18. 440 F.2d 803 (2d Cir. 1971), noted in 38 Brooktry L. REv. 1005 (1972) and 46 ST. JohN's L. REV. 425 (1972).

19. Eisner v. Stamford Bd. of Educ., 314 F. Supp. 832 (D. Conn. 1970). The regulation in Eisner stated: "No person shall distribute any printed or written matter on the grounds of any school or in any school building unless the distribution of such material shall have prior approval by the school administration." Id. at 899. The board's published guidelines for granting or denying approval specified:

No material shall be distributed which, either by its content or by the Inanner of distribution itself, will interfere with the proper and orderly operation and discipline of the school, will cause violence or disorder, or will constitute an invasion of the rights of others.

Id. at 834 .

20. In its opinion, the Second Circuit said:

We do not agree with the district court, however, that reasonable and fair regula. tions which corrected those [procedural] defects but nevertheless required prior submission of material for approval, would in all circumstances be an unconstitutional "prior restraint."

440 F.2d at 805 .

21. In Eisner, the court developed its view of adequate procedural safeguards from Freedman v. Maryland, 380 U.S. 51 (1965). See 440 F.2d at 810 . Freedman held that regulation of obscenity in motion pictures could be accomplished through a licensing system, if accompanied by adequate procedural guidelines. The court in Eisner required a speedy initial clearance procedure and a clear specification of to whom and how material was to be submitted. Id. at $810 \cdot 11$. Some cases since Eisner have, in ad. dition, required a prompt review procedure of any initial denial of approval by school officials. See notes $25 \& 27$ infra.

22. 453 F.2d 54 (4th Cir. 1971).

23. The regulation challenged in Quarterman provided: "Each pupil is specifically prohibited from distributing. while under school jurisdiction, any advertisements, painphlets, printed material, announcements or other paraphernalia without the express permission of the principal of the school." $453 \mathrm{~F} .2 \mathrm{~d}$ at 55 . 
down the rule, not because prior restraints are impermissible,,$-t$ but because the rule had procedural defects.5 The Fifth Circuit also followed the lead of Eisner in Shanley v. Northeast Independent School District, ${ }^{26}$ involving the distribution of an underground newspaper. Under the particular facts of this case-the distribution was off-campus and not during school hours, the newspaper was innocuous and there were procedural inadequacies ${ }^{27}$-the court held that the prior restraint was unconstitutional. But the court clearly stated its agreement with the view in Eisner that "[t]here is nothing unconstitutional per se in a requirement that students submit materials to the school administration prior to distribution."28

By contrast, the Seventh Circuit, in Fujishima v. Board of Education, ${ }^{29}$ held prior restraints unconstitutional. The case involved a Chicago Board of Education rule which was almost identical to the regulation challenged in Eisner. ${ }^{30}$ Two plaintiffs in Fujishima had been suspended for circulating 350 copies of an underground newspaper before and between classes and during lunch breaks. A third had been suspended twice: once for giving another student an unsigned copy of a petition calling for a teach-in concerning the war in Vietnam; and once for handing out fifteen to twenty leaflets about the war during a fire drill, while he and his classmates were in their assigned positions. The court declined to confine its ruling to the procedural deficiencies of the regulation. Eisner's approval of prior restraints, according to this court, was "unsound constitutional law." 31

24. [S]chool authorities may by appropriate regulation, cxercise prior restraint upon publications distributed upon school premises during school hours in those special circumstances where they can "rcasonably 'forccast substantial disruption of or material interference with school activities" " on account of the distribution of such printed material.

Id. at 58 .

25. In addition to the requirements stated in Eisner, see note 21 supra, Quarterman required a permissible rule to have "procedural safeguards in the form of an "cxpeditious review procedure" of the decision of the school authorities." Id. at 59 .

26. 462 F.2d 960 (5th Cir. 1972). The regulation in Shanley read:

$\mathrm{Be}$ it further resolved that any attempt to avoid the school's established procedure for administrative approval of activities such as the production for distribution and/or the distribution of petitions or printed documents of any kind, sort, or type without the specific approval of the principal shall be cause for suspension.....

Id. at 965 n.l. Five students in Shanley were suspended for violating this provision.

27. The court in Shanley required a clear statement as to the means by which students were to submit material to school officials, a speedy decision by these officials, an appellate mechanism, and a reasonably prompt decision by this mechanism. Id. at 978 .

28. Id. at 969 .

29. 460 F.2d 1355 (7th Cir. 1972).

30. The school regulation challenged in Fujishima read: "No person shall be permitted ... to distribute on the school premises any books, tracts, or other publications, .. unless the same shall have been approved by the General Superintendent of schools." Id. at 1356 .

31. Id. at 1359 . 
These cases ${ }^{32}$ and their progeny ${ }^{33}$ indicate the need for an authoritative resolution of the prior restraint question. That resolution requires a fuller understanding of the Tinker test and an inquiry into the nature of the high school as an institution.

On its face, the Tinker rule, which permits regulation to be based on a "forecast" of disorder, might seem to sanction prior restraints as a means of making that forecast. This possibility must be dismissed, however, when the relationship of the Tinker test to other tests is understood. Consider the "clear and present danger" and the "incitement" tests. ${ }^{34}$ They are of the same type as the Tinker test in two respects. First, each identifies a level of disorder justifying state regulation of speech. And second, each is "prediction" oriented: Neither requires the state to wait until the forbidden level of disorder has developed before taking action. But neither test-notwithstanding the sanction for regulation based on prediction-has been thought to authorize prior restraints as a means of disorder prediction. ${ }^{35}$ These tests differ from the Tinker test in the level of disorder which justifies regulation, nol in the means of prediction which are appropriate.

This reading of Tinker, concluding that its test provides no justification for prior restraints in high schools, is supported at a number of

32. Another case, Riseman v. School Committee, 439 F.2d 148 (1st Gir. 1971), pre. ceded Eisner, and seems to have taken a position approving prior restraints, but did 110 t explicitly so state. In commenting upon a school regulation the court said, "More ill. portantly, as sought to be applied to First Amendment activities, it . . . does not reflect any effort to minimize the adverse effect of prior restraint, Freedman v. Maryland, 980 U.S. 51 ..." $439 \mathrm{~F} .2 \mathrm{~d}$ at $149-50$. The statement implies that prior restraints may be permissible if procedurally sound. The citation of Freedman adds wcight to this in. ference, since that case held that censorship of obscenity in motion pictures could be accomplished through a licensing scheme, if accompanied by adequate procedural guidclines. See note 47 infra.

33. Koppell v. Levine, 347 F. Supp. 456 (E.D.N.Y. 1972), involved a suit to obtain at declaratory judgment that a system of prior restraints imposed by a New York City high school was unconstitutional. Though the court refused to reach this issuc, becalusc the case did not involve an actual dispute, it made clear that it would follow Eisner in permitting prior restraints if accompanied by adequate procedural guidelines. $J d$. at 464-65.

In Baughman v. Freienmuth, 343 F. Supp. 487 (D. Md. 1972), students sought a de. claratory judgment as to the unconstitutionality of a rule requiring all non-schiool sponsored student publications to be approved by the school principal prior to clistribution in the school. The court followed Quarterman in permitting prior restraints and in requiring adequate procedures for initial determination. However, whereas Quarterman had required an appeals procedure, arguably on a misreading of Eisner (Compare 440 F.2d at 810-11 with 453 F.2d at 59-60), the district court concluded that Quarterman held only that the Eisner safeguards were applicable, and proceeded to read Eisner for itself. The result was that the court did not require an appeals procedure. See 343 F. Supp. at 492.

34. See note 9 supra.

35. See note 9 \& p. 1327 supra. 
points in the opinion. First, there is the Court's reference in the test itself to the need for "facts" as the basis for a prediction of disruption. ${ }^{30}$ It is apparently such "facts" which distinguish a valid "prediction" of disturbance from the "undifferentiated fear or apprehension of disturbance [which] is not enough to overcome the right to freedom of expression" in high schools. ${ }^{37}$

It might be argued that the special institutional characteristics of high schools warrant prior restraints, even though they are not permitted in society at large. Certainly some institutions, such as the military, prisons and mental hospitals, impose severe restrictions on the rights of their inmates to engage in speech or to communicate with others. ${ }^{38}$ But for First Amendment purposes, if not for others, the differences between these institutions and schools are more important than their similarities. The similarities are primarily that both kinds of institution perform a function which requires the exercise of disciplinary control over the lives of their "inmates." But the other institutions were created to serve distinct purposes: protecting national security, or segregating criminal offenders and sometimes rehabilitating them. Schools, by contrast, have the judicially-acknowledged purpose of preparing students to be fully participating citizens-a purpose which requires, among other things, that schools serve as an arena for free expression, in which citizens first flex (and appreciate) the First Amendment rights of speech. ${ }^{39}$

36. See p. 1329 supra.

37. 393 U.S. at 508 .

38. For commentaries on prison inmates First Amendment rights, see the collection of sources cited in Note, Prison Mail Censorship and the First Amendment, 81 Yale L.J. $87 \mathrm{n.5}$ (1971). An excellent discussion of the First Amendment rights of members of the military is in Sherman, The Afilitary Courts and Servicemen's First Amendment Rights, 22 Hastincs L.J. 325 (1971).

39. In his opinion for the Court in Tinker, Justice Fortas said:

The principal use to which the schools are dedicated is to accommodate students during prescribed hours for the purpose of certain types of activities. Among these activities is personal intercommunication among the students. This is not only an inevitable part of the process of attending school; it is also an important part of the educational process.

393 U.S. at 512.

Earlier Supreme Court cases which dealt with teachers', rather than students' rights, also affirmed the basic harmony between educational goals and the purposes of the First Amendment. In Keyishian v. Bd. of Regents, 385 US. 589 (1967), quoted in Tinher, Justice Brennan, speaking for the Court, said:

The classroom is peculiarly the "marketplace of ideas." The Nation's [uture depends upon leaders trained through wide exposure to that robust exchange of ideas which discovers truth "out of a multitude of tongues, (rather) than through any kind of authoritative selection." United States v. Associated Press, 52 F. Supp. $362,372$. Id. at 603 .

Keyishian, in turn, quoted Shelton v. Tucker, 364 US. 479 (1960), where the Court said, "The vigilant protection of constitutional freedoms is nowhere more vital than in the community of American schools." 364 U.S. at 487. 
Moreover, Tinker itself forecloses any justification for prior restraints based on an analogy to more rigid institutions. "School officials," the Court noted, "do noi possess absolute authority over their students." 40 The Court also cites approvingly a district court opinion which "pointed out that a school is not like a hospital or a jail enclosure." 11 It is no totalitarian "enclave" in need of special speech restrictions. ${ }^{42}$

The discussion thus far has assumed the non-existence of extraordinary problems of order and discipline. The presence of such problems, resulting from circumstances of stress and agitation, would not seem to justify imposition of a system of advance submission. As always, expression may be controlled by reasonable regulations of time, place, and manner. Reasonableness, of course, depends on the environment in which expression is published. In a high school with a tense atmosphere more stringent rules would be appropriate, i.e., there might be fewer places and times when the distribution of material would be reasonable. Restraints would apply to any material, without prior scrutiny of content. Also, the reasonableness of the regulations established would be subject to challenge in court. ${ }^{43}$

In sum, neither the nature of the Tinker test, nor the nature of the high school as an institution, whether in calm or stormy times, warrants prior restraints in high schools where they would not be warranted in society at large.

IV

Outside the school context, obscenity is the only area in which prior restraints on the distribution of printed matter may be permissible. If, as argued, the proper test for the validity of prior restraints in high school is their validity in analogous non-school situations, the question remains whether obscenity provides an adequate rationale for a high school system requiring the prior screening of publications.

The restrictions on obscenity restraints in society at large are so severe as practically to foreclose a prior restraint system..$^{4 *}$ While the Supreme Court has acknowledged "the State's power to prevent the distribution of obscene matter," 45 the only statutory scheme it has

40. 393 U.S. at 511.

41. Id. at 512 n.6.

42. Id. at 511 .

43. See p. 1327 supra.

44. See Monaghan, supra note 13 , at 539 .

45. Smith v. California, 361 U.S. 147, 155 (1959). 
approved for printed materials-that of New York ${ }^{\text {t3 }}$-did not require advance submission. ${ }^{47}$ Instead, the New York system placed the burden on city officials to discover the obscene materials, and seek an injunction against the sale or distribution of specific items. This precedent would not appear to justify a system which required the advance submission of all published matter in the search for obscenity, either within or without the high school context.

Moreover, obscenity, properly defined, has not been the primary issue in the cases which have arisen since Tinker. Advocacy of militant action, ${ }^{48}$ controversial opinions, ${ }^{49}$ borderline libel, ${ }^{50}$ and vulgar or profane language $^{51}$ are the aspects of such journalism that seem to cause concern-and these cannot be reached by a restraint couched in terms of obscenity. ${ }^{52}$

46. See Kingsley Books, Inc. v. Brown, 354 U.S. 436 (195n).

47. Thus far, the Supreme Court has sanctioned a permit system only when applied to motion pictures. See Freedman v. Maryland, 380 U.S. 51 (1965).

48. In Quarterman, for example, one of the undenground newspapers distributed by the students concluded an article with an exhortation, in capital letters, reading in part as follows:

We have to be prepared to fight in the hall and in the classrooms, out in the strcets because the schools belong to the people. If we have to-we'll burn the buildings of our schools down to show these pigs that we want an education that won't brainwash us into being racist ....

453 F.2d at $55-56$.

49. One of the student plaintiffs in Fujishima had been suspended for distributing leaflets and petitions concerning the war in Victnam. $460 \mathrm{F.2d}$ at 1356. In addition, student publications have sometimes criticized existing school policy and, by necessary implication, the school officials who formulate it. See, e.g., Scoville v. Board of Educ., 425 F.2d 10 (7th Cir. 1970), cert. denied, 400 U.S. 826 (1970).

50. Sometimes, the publications which incur the greatest administrative wrath are those which criticize or ridicule high school officials. See, e.g., Sullivan y. Houston, 307 F. Supp. 1328 (S.D. Tex. 1969). Students published a newspaper which included a satire in the form of a speech by a hypothetical administrator. Id. at 1348 . The court refused to permit the regulation of non-libelous attacks on school officials. Id. at 1341 .

In Schwartz v. Schuker, 298 F. Supp. 238 (E.D.N.Y. 1969), a high school student was suspended for his attempt to distribute a publication which referred to the principal as "King Louis," "a big liar" and a person having "racist vievs and attitudes." Id. at 240.

51. In Koppell v. Levine, 347 F. Supp. 456 (E.D.N.Y. 1972), the court characterized language in the publication as "the kind heard repeatedly by those who walk the street [sic] of our cities .... and deal with youth in an open manner." 347 F. Supp. at 439. The court found, however, that it was not subject to regulation on obscenity grounds because it "contained no extended narrative tending to excite sexual desires or constituting a predominant appeal to prurient interest." Id.

Sullivan v. Houston Ind. School Dist., 333 F. Supp. 1149 (S.D. Tex. 1971), held that a newspaper containing a letter to the editor which several times used variants of the word "fuck" was not obscene, but simply vulgar. Accordingly, it could not be restrained by school officials. Id. at 1162-67.

52. The Supreme Court has recently made clear that more than vulgarity or pro. fanity is needed to bring into play a state's authority to regulate obscenity. In Cohen v. California, 403 U.S. 15 (197I), Cohen wore a jacket bearing the words "Fuck the Draft" into a corridor of a courthouse. The Court held the expression was not obscene and said, "Whatever else may be necessary to give rise to the States" broader power to prohibit obscene expression, such expression must be, in some significant way, crotic." ld. at 20. See note 51 supra. 
With the diminution of dissent, there may be diminished inclination to challenge school regulations governing distribution of materials on campus. Absence of challenge (or tacit acceptance) would be unfortunate, since it would prolong the life of an undesirable precedent sanctioning the imposition of prior restraints.

At some time, almost certainly, the question will be raised again. Then courts will hopefully adopt the sound position taken by the Seventh Circuit, forbidding prior restraints. In the circuits which have adopted a contrary view, the matter deserves reconsideration. 